\title{
SISTEM RELIGI PADA MASYARAKAT KASEPUHAN CICARUCUB PROUINSI BANTEN
}

\author{
Oleh Ria Andayani S. \\ Balai Pelestarian Sejarah dan Nilai Tradisional Bandung \\ Jln. Cinambo No. 136 Ujungberung Bandung \\ Email: riaandayanisomantri@yahoo.com
}

\begin{abstract}
Abstrak
Sistem religi masyarakat Kasepuhan Cicarucub diwarnai oleh dua unsur penting, yakni agama dan kepercayaan warisan nenek moyang mereka. Mereka menganut agama Islam, namun mereka juga masih mempertahankan dan melaksanakan kepercayaan warisan leluhur. Kepercayaan yang mereka anut, teraktualisasikan dalam adat istiadat mereka yang tampak khas, seperti dalam bidang pertanian, kepemimpinan, dan aktivitas daur hidup manusia. Dengan kata lain, agama dan adat istiadat menjadi pedoman hidup warga masyarakat Kasepuhan Cicarucub. Oleh karena itu, kedua unsur tersebut berjalan harmoni dalam kehidupan mereka sehari-hari.
\end{abstract}

Kata Kunci: Sistem religi, masyarakat Kasepuhan.

\begin{abstract}
Religy'system of Kasepuhan Cicarucub's society was built by two important thing. Those are religion and ancestor's belief. They are Moslem, although they still keep and do their ancestor's belief who are shown in the unique customs, such as agriculture, leadership. And life cycle. So, religion and customs become a way of life for them and give them a harmonic life.
\end{abstract}

Keywords: Religy's system, custom society.

\section{A. Pendahuluan}

Provinsi Banten merupakan salah satu provinsi baru di wilayah Republik Indonesia. Daerah pecahan dari Provinsi Jawa Barat ini memiliki karakteristik yang khas, terutama bila dilihat dari latar belakang budaya masyarakatnya. Di beberapa tempat terdapat kelompokkelompok masyarakat yang masih tetap bertahan dengan tatanan pola kehidupan lama warisan leluhur. Kelompok masyarakat yang masih mempertahankan pola kehidupan lama seperti itu biasa disebut komunitas adat.

Keberpihakan komunitas adat terhadap adat isitiadat warisan leluhur menjadikan mereka tampak unik di tengah kehidupan masyarakat Indonesia yang terus berubah. Mereka menjadi salah satu benteng terakhir pelestari budaya lokal di Indonesia. Di sanalah tempatnya, kearifan budaya lokal tersimpan dan diaktualisasikan dalam adat istiadat komunitas tersebut. Kearifan lokal sendiri merupakan kristalisasi hasil adaptasi mereka terhadap berbagai ling- 
kungan yang mengelilingi kehidupan manusia.

Salah satu dari lingkungan tadi adalah lingkungan transendental, yang memberi warna pada sistem religi suatu komunitas adat. Sistem religi adalah sistem pemikiran dan tindakan yang mengekspresikan kepercayaan kepada Tuhan, termasuk juga keyakinan akan adanya kekuatan gaib para leluhur atau roh-roh halus yang dianggap mempengaruhi kehidupan manusia. Sistem religi sendiri merupakan tanggapan aktif mereka dalam menghadapi lingkungan transendentalnya atas berbagai fenomena yang terjadi di dalam kehidupan mereka.

Mengingat betapa pentingnya keberadaan sistem religi dalam kehidupan komunitas adat, dipandang perlu untuk melakukan penelitian tentang hal itu pada salah satu komunitas adat di Provinsi Banten, yakni masyarakat Kasepuhan Cicarucub. Penelitian tersebut dilakukan untuk menjawab masalah yang dirumuskan dalam pertanyaan, "Bagaimanakah sistem religi masyarakat Kasepuhan Cicarucub?" Adapun tujuan yang ingin dicapai melalui penelitian tersebut adalah untuk mengetahui sistem religi pada masyarakat Kasepuhan Cicarucub.

Ruang lingkup penelitian meliputi dua hal. Pertama, ruang lingkup materi yang mencakup gambaran umum lokasi penelitian dan sistem religi pada masyarakat Kasepuhan Cicarucub. Adapun ruang lingkup wilayah penelitian dibatasi di Kasepuhan Cicarucub, Desa Neglasari, Kabupaten Lebak, Provinsi Banten. Pertimbangan memilih wilayah ini didasarkan pada karakteristik wilayah tersebut yang diperkirakan masih mempertahankan dan melaksanakan religi warisan nenek moyangnya.

Penelitian tentang Sistem Religi pada Masyarakat Kasepuhan Cicarucub di Provinsi Banten merupakan jenis penelitian yang bersifat deskripsi atau menggambarkan. Penelitian deskriptif ini bertujuan menggambarkan secara tepat sifat-sifat suatu gejala sosial, baik individu-individu, kelompok-kelompok, dan keadaan sosial tertentu. Oleh karena itu, pendekatan atau metode yang digunakan dalam penelitian ini adalah metode deskriptif-kualitatif.

$$
\text { Zulyani Hidayah }
$$

menjelaskan, pendekatan kualitatif digunakan untuk memahami persoalan sosial atau budaya manusia berdasarkan pada suatu pengembangan gambaran yang kompleks dan holistis, dibangun dengan susunan kata, menyajikan pandangan detil dari informan dan dilaksanakan di lingkungan alamiahnya. Metode kualitatif juga dilaksanakan dalam situasi yang memungkinkan peneliti berinteraksi secara langsung dengan orang-orang yang diteliti, dalam upaya memperoleh data dari sumber pertama. Teknik pengumpulan data di lapangan yang digunakan adalah pengamatan dan wawancara.

Pengamatan merupakan teknik pengumpulan data lapangan yang cukup penting. Sasaran pengamatan adalah kejadian-kejadian atau fakta-fakta sosial yang berhubungan dengan sistem religi pada masyarakat Kasepuhan Cicarucub. Pengamatan dilakukan terhadap lingkungan alam, sosial, dan budaya yang terkait dengan materi penelitian.

Wawancara juga merupakan teknik penelitian yang tidak kalah pentingnya dengan pengamatan. Teknik penelitian yang satu ini dilakukan untuk memperoleh data terkait dengan materi yang ingin dijaring melalui penelitian tersebut. Sebagai panduan, dibuat instrumen penelitian berupa pedoman wawancara yang berisi sejumlah pertanyaan terbuka untuk menggali data mengenai religi pada masyarakat Kasepuhan Cicarucub. Wawancara secara mendalam dilakukan 
kepada sejumlah warga Cicarucub yang dipandang menguasai atau memahami materi dalam penelitian ini. Dalam melakukan wawancara digunakan alat bantu, perekam suara (tape recorder). Selain teknik pengumpulan data di lapangan berupa pengamatan dan wawancara, studi pustaka juga dilakukan. Hal itu bertujuan untuk memperoleh informasi yang berhubungan dengan materi pendataan dari berbagai literatur, seperti buku, surat kabar, majalah, jurnal, dan makalah.

\section{B. Hasil dan Bahasan}

Kasepuhan Cicarucub secara administratif masuk dalam wilayah Desa Neglasari, Kecamatan Cibeber, Kabupaten Lebak, Provinsi Banten. Wilayah Kasepuhan Cicarucub meliputi tiga kampung, yakni Kampung Cicarucub Girang, Cicarucub Tengah, dan Cicarucub Hilir. Kasepuhan Cicarucub merupakan salah satu satu komunitas adat di Provinsi Banten, yang relatif masih mampu mempertahankan tatanan kehidupan lama warisan nenek moyangnya. Oleh karena itu, warna budaya masyarakat Kasepuhan Cicarucub tampak khas. Kekhasan itu terlihat pada salah satu unsur budaya mereka, yakni sistem religi.

Sistem religi masyarakat Kasepuhan Cicarucub diwarnai oleh dua unsur penting, yakni agama dan kepercayaan warisan nenek moyangnya. Dalam hal ini, mereka menganut agama Islam, namun mereka juga masih mempertahankan dan melaksanakan kepercayaan warisan leluhur. Kepercayaan tersebut telah teraktualisasikan ke dalam adat istiadat mereka yang tampak khas. Dengan demikian, agama dan adat istiadat menjadi pedoman hidup mereka sebagai pemeluk agama Islam dan sebagai warga masyarakat Kasepuhan Cicarucub. Kedua unsur tersebut berjalan harmonis mengatur roda kehidupan mereka sehari-hari.

Masyarakat Kasepuhan Cicarucub menganut agama Islam sebagai pedoman hidup yang mereka yakini kebenarannya. Mereka memaknai dan mengimani ajaran agama yang dianutnya, serta mengaktualisasikannya dalam kehidupan sehari-hari. Salah satu aktualisasi keimanan mereka diwujudkan dalam sejumlah aktivitas keagamaan, baik yang dilaksanakan secara individu maupun kolektif.

Aktivitas keagamaan yang bersifat individu merupakan ekspresi kedekatan hubungan warga masyarakat Cicarucub secara pribadi dengan Tuhannya. Mereka melaksanakan segala perintah dan ajaran Tuhan, serta menjauhi larangan-Nya tanpa perlu melibatkan dan tanpa harus diketahui orang lain. Mereka berbuat kebaikan, melakukan shalat, mengaji, dan aktivitas keagamaan lainnya sendiri di rumah, di mesjid, atau dimana saja bergantung pada keinginan individu tersebut. Masyarakat Kasepuhan Cicarucub tidak hanya melakukan aktivitas keagamaan secara individu, aktivitas keagamaan yang bersifat kolektif juga tampak berkembang dalam kehidupan mereka sehari-hari. Yang dimaksud di sini adalah mereka melaksanakan satu aktivitas keagamaan secara bersama-sama dalam waktu dan atau tempat yang sama. Orang yang paling berperan dalam menjaga kelangsungan aktivitas keagamaan yang bersifat kolektif adalah tokoh agama, seperti ustad dan kyai.

Kebersamaan dalam aktivitas keagamaan dapat terjadi tanpa direncanakan atau berlangsung secara spontan; dan ada pula kebersamaan yang terjalin karena direncanakan, dengan cara membentuk suatu kelompok tertentu. Mereka percaya, kebersamaan dalam melaksanakan aktivitas keagamaan dapat 
mendatangkan pahala yang berlipat ganda, mempertebal keimanan mereka, dan mempererat hubungan sosial masyarakat Kasepuhan Cicarucub.

Aktivitas keagamaan yang dilakukan secara bersama-sama di antaranya kegiatan shalat, merayakan hari-hari besar keagamaan, dan membaca Alquran atau mengaji. Shalat adalah salah satu perintah Tuhan kepada umat Islam, dengan kekuatan hukum yang bernilai wajib dan sunat untuk dilaksanakan. Dalam hal ini, warga masyarakat Kasepuhan Cicarucub memiliki kebiasaan melaksanakan shalat bersamasama atau berjamaah.

Aktivitas keagamaan lainnya yang biasa dilakukan secara bersama-sama adalah perayaan hari-hari besar agama Islam, seperti Idul Fitri, Idul Adha, Isra Miraj, Rajaban, dan Maulud Nabi. Pada saat-saat seperti itu, mereka akan memperingatinya secara bersama-sama.

Di seputar peringatan hari-hari besar keagamaan, hidup dan berkembang tradisi masyarakat yang khas dan mungkin berbeda dengan mereka yang tinggal di tempat lain. Beragam tradisi dilaksanakan untuk menyambut dan menyemarakkan suasana peringatan harihari besar keagamaan. Tradisi itu dapat berupa ritual-ritual upacara, kebiasaankebiasaan, pantangan-pantangan, maupun makanan tertentu yang khusus disajikan pada kesempatan tersebut. Contohnya, mereka menyemarakkan Idul Fitri dengan membuat kue-kue khas Lebaran; melaksanakan kegiatan saling mengunjungi sanak saudara dan tetangga untuk tujuan saling meminta maaf satu sama lainnya; dan berziarah ke makam leluhur mereka.

Ada satu lagi aktivitas keagamaan yang sengaja dilakukan bersama-sama oleh masyarakat Kasepuhan Cicarucub, yakni kegiatan membaca ayat-ayat suci Alquran atau mengaji. Mereka tidak hanya membaca Alquran dan mencoba memahami isinya. Mereka juga menjadikan Alquran sebagai ukuran hidup bagi mereka, yang dipahami dengan caranya sendiri. Dalam pandangan mereka, bunyi-bunyi huruf hijaiyah merupakan simbol nilai-nilai kehidupan yang seharusnya dianut oleh mereka. Setiap bunyi huruf hijaiyah, ada yang bermakna satu nilai tertentu, ada juga yang harus digabungkan dengan huruf hijaiyah yang lainnya. Beberapa contoh di antaranya adalah sebagai berikut:

- $\quad$ Alip=alili, emutan kedah lempeng (harus berpikiran lurus).

- Be=bentes, yakni ulah ngawadul tapi kudu jujur (jelas dalam berbicara, yakni tidak boleh berdusta melainkan harus jujur).

- $\quad T s a(s a=\underline{\text { saha}}$-saha kedah (siapapun harus).

- Ja=jarang, ulah jarang papendak, jadi kudu silaturahim (jarang, jangan jarang bertemu, jadi harus bersilaturahim).

- Ha=hade, hade sareng pada bangsa, ulah papaseaan wae antarumat manusa ( Akur, akur dengan bangsa lain, jangan bertengkar saja dengan sesama manusia)

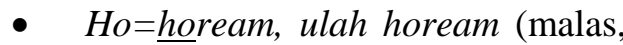
jangan malas).

- Dal=daek, ulah henteu bisi balangsak (mau bekerja, jika tidak, akan sengsara).

- Da=daek, ulah henteu bisi balangsak (mau bekerja, jika tidak, akan sengsara).

- Re=rela, dipasihan sagala kedah rela (rela atau ikhlas, diberi segala sesuatu harus ikhlas).

- Ja=jarang, ulah jarang papendak, jadi kudu silaturahim (jarang, 
jangan jarang bertemu, jadi harus bersilaturahim).

- $\quad$ Sin=sing kedah gaduh kaisin (harus mempunyai rasa malu).

- Sya=saha-saha kedah (siapapun harus).

- $\quad$ Sod=soleh, kedah soleh hate (soleh, hati harus soleh).

- Do = singkade kabobodo (hati-hati tertipu).

- To=kedah toat kanu maha kawasa, ka ibu rama, ka pamarentah, jeung ka karuhun urang ( harus taat kepada Yang Maha Kuasa, kepada orang tua, kepada pemerintah, dan kepada leluhur atau nenek moyang kita).

- Do=singkade kabobodo (hati-hati tertipu).

- $\quad$ ngain=ngade (kade) bilih lepat, jadi kudiu ati-ati (awas jangan salah, jadi harus hati-hati).

- Mim=-mana anu urang candak, mana anu batur ulah dicandak (ambilah yang menjadi milik kita, jangan mengambil yang menjadi milik orang lain).

- $\quad N u n=\underline{n u}$ saha (barang siapa).

- Wa=kudu wawuh, jadi hayang kaaku (harus kenal, jadi ingin diakui keberadaannya).

- Hamjah=hade, sing hade (baik, jadilah orang yang baik)

- $\quad$ Iyah=sing jujur, sing leres (harus jujur, harus benar).

- $\quad A=$ aturan urang (aturan kita)

- $\quad I=t u j u a n$ urang (tujuan kita)

- U=ukuran urang (ukuran kita)

Mengaji tidak hanya bagian dari aktivitas keagamaan, melainkan juga merupakan bagian dari adat istiadat masyarakat Kasepuhan Cicarucub yang diwariskan oleh nenek moyangnya. Yang dimaksud di sini bukan mengaji Alquran, melainkan mengaji diri atau ngaji diri. Pada masyarakat Kasepuhan Cicarucub, ngaji diri merupakan salah satu upaya pembinaan moral. Menurut mereka, ngaji diri berarti mawas diri, memahami diri sendiri, sekaligus juga bermakna mengoreksi diri.

Ajaran tersebut bertujuan untuk melawan sifat buruk dalam diri manusia agar dia terhindar dari jalan yang bertentangan dengan perintah nenek moyang atau leluhurnya. Salah satu contoh dari ngaji diri tampak dalam uraian nilai-nilai kehidupan yang seharusya dianut oleh mereka tadi. Kebiasaan ngaji diri merupakan salah satu unsur kepercayaan warisan nenek moyang yang masih dipelihara dan dipertahankan oleh mereka.

Sebagai warga Kasepuhan Cicarucub, mereka masih memelihara kepercayaan yang diwariskan oleh nenek moyangnya sampai saat ini. Kepercayaan itu tidak beridiri sendiri secara khusus, namun telah teraktualisasikan ke dalam adat istiadat mereka, dan menjadi pedoman hidup yang sangat penting bagi kehidupan mereka.

Dalam kepercayaan mereka, ada hal yang perlu mendapat perhatian, yakni konsep untuk mempersatukan dunia nyata dan dunia gaib, atau makro dan mikro kosmos untuk mencapai satu kesatuan hidup. Keduanya harus disatukan karena saling berhubungan satu sama lainnya. Kegiatan apapun yang dilakukan mereka di dunia nyata akan berhubungan dengan dunia gaib. Oleh karena itu, keharmonisan di antara keduanya harus senantiasa dijaga dengan baik.

Dunia nyata adalah alam yang yang dapat dilihat oleh mata, dan menjadi tempat makhluk hidup melangsungkan kehidupannya. Makhluk hidup yang mengisi dunia nyata adalah manusia, hewan, dan tumbuh-tumbuhan. Kewajiban manusia, dalam hal ini masyarakat Kasepuhan Cicarucub di dunia nyata 
adalah harus melakukan kegiatan bercocok tanam dan menjaga tali paranti atau adat istiadat yang diwariskan oleh leluhurnya.

Dunia gaib adalah dunia atau alam yang tidak dapat dilihat oleh mata, namun diyakini keberadaannya oleh masyarakat Kasepuhan Cicarucub. Yang mengisi dunia gaib adalah entitas supranatural atau supernatural yang terdiri atas karuhun atau leluhur, dewadewi, dan makhluk-makhluk gaib lainnya. Ketiga hal tersebut akan dijelaskan satu persatu.

Karuhun atau leluhur adalah warga masyarakat Kasepuhan Cicarucub yang sudah meninggal. Di antara leluhur itu, ada yang menempati kedudukan istimewa dalam kehidupan masyarakat Kasepuhan Cicarucub. Dia diistimewakan karena merupakan cikal bakal masyarakat setempat, pendiri kampung, atau pernah menjadi ketua adat masyarakat setempat. Leluhur memiliki karakteristik seperti itu disebut karamat oleh masyarakat setempat.

Pengistimewaan tersebut dilakukan dengan cara tetap mempertahankan dan memelihara makamnya agar selalu dapat dingat oleh generasi penerusnya. Makamnya pun biasanya disebut makam karamat, yakni makam leluhur kampung yang biasa diziarahi pada saat akan melakukan aktivitas pertanian, seperti sebar,melak, mipit, juga tutup taun saur bulan (panen).

Di Kasepuhan Cicarucub terdapat makam karamat Olot Edot yang biasa disebut pula astana uyut atau astana girang. Selain itu ada makam karamat Bibi Muni, terletak di Gunung Gudang. Kedua makam tersebut dikeramatkan oleh mereka, serta diziarahi pada saatsaat tertentu, seperti ketika akan melakukan aktivitas pertanian, beragam upacara tradisional, dan kepentingan pribadi lainnya.
Pengistimewaan leluhur juga dilakukan dengan cara selalu mengingat namanya agar peran dan jasanya yang penting diketahui oleh generasi-generasi berikutnya. Orang-orang yang pernah menjadi ketua adat di tempat tersebut, setidaknya akan tetap diingat namanya oleh para pemangku adat yang ada sekarang.

Leluhur menempati kedudukan yang penting dalam kehidupan masyarakat Kasepuhan Cicarucub, karena dianggap telah berjasa membuat mereka sekarang ada. Mereka dapat berada di alam nyata saat ini, karena dilahirkan oleh generasi-generasi sebelumnya. Oleh karena itu, mereka memiliki kewajiban untuk tetap menghormati leluhurnya. Mereka memperlakukan leluhur seolaholah masih berada di antara mereka.

Ada beberapa cara yang dilakukan masyarakat Kasepuhan Cicarucub untuk menghormati leluhurnya. Pertama, mereka senantiasa numbal, yakni membakar kemenyan, mengunyah panglay, kemudian menyemburkannya dari mulut ke berbagai penjuru arah mata angin. Bila diperlukan mereka menambahkan sesaji yang terdiri atas kemenyan, makanan, dan minuman yang menjadi kesukaan leluhurnya pada malam-malam tertentu. Numbal merupakan simbol permohonan izin kepada leluhur sebelum melakukan kegiatan sosial, pertanian, dan upacara tradisional.

Kedua, mereka harus taat kepada leluhur, dengan cara tetap menjaga apaapa yang telah diwariskannya, yakni tetap melakukan aktivitas pertanian dan memelihara tali paranti atau adat istiadat warisan leluhurnya. Semua itu dilakukan untuk menjaga hubungan yang harmonis antara masyarakat Kasepuhan Cicarucub dan leluhurnya. Jangan sampai leluhurnya merasa tidak diperhatikan oleh mereka sehingga bisa membuatnya tersinggung, atau bahkan marah. 
Entitas supranatural lainnya yang ada dalam dunia gaib di Kasepuhan Cicarucub adalah Nyi Sri atau Dewi Sri, yakni ruh suci yang menjelma menjadi padi. Oleh karena itu, Dewi Sri juga sering disebut Dewi Padi. Dalam pandangan masyarakat Kasepuhan Cicarucub, padi merupakan suatu tanaman yang dianggap suci. Oleh karena itu, padi harus diperlakukan dengan baik, sejak padi ditanam hingga dimanfaatkan untuk memenuhi berbagai kebutuhan hidup manusia.

Masyarakat Kasepuhan Cicarucub memperlakukan Dewi Sri begitu istimewa, tetapi bukan berarti mereka migusti atau menjadikannya sebagai Tuhan. Yang dilakukan oleh mereka hanyalah mupusti atau memelihara dan merawatnya. Mereka memperlakukannya seperti itu, karena padi telah memberikan daya hidup bagi mereka. Menanam padi menjadi mata pencaharian utma mereka, dan merupakan salah satu tradisi yang diwariskan oleh leluhurnya; Padi juga merupakan sumber pangan utama dan bahan dasar berbagai olahan makanan pendamping yang dikonsumsi oleh mereka. Oleh karena itu, padi menjadi sesuatu yang sangat penting dan berarti bagi mereka sehingga mendapat perlakuan yang istimewa.

Masyarakat Kasepuhan Cicarucub mempersonifikasikan Dewi Sri sebagai seorang perempuan dengan segala karakteristiknya. Mereka senantiasa menjaga Dewi Sri agar selalu tetap cantik, menikmati apa yang menjadi kesukaannya, terhindar dari segala sesuatu yang tidak disenanginya, tidak tersakiti apalagi sampai membuatnya marah. Jika kondisi demikian terjaga dengan baik, diyakini akibatnya akan berimbas pada aktivitas pertanian mereka, yakni akan memperoleh hasil panen yang melimpah. Konsekuensinya, kehidupan mereka juga akan sejahtera.
Sebaliknya jika mereka tidak dapat menjaga kondisi seperti itu, dipercaya akan berakibat buruk terhadap kegiatan pertanian mereka. Untuk menjaga dan menghormati Nyi Sri, ada sejumlah tradisi yang dilaksanakan oleh masyarakat Kasepuhan Cicarucub terkait dengan keberadaan padi.

Pertama, mereka memiliki kebiasaan numbal, yakni menyajikan membakar kemenyan, mengunyah panglay, kemudian menyemburkannya ke berbagai penjuru arah mata angin, pada padi, dan berbagai benda yang berhubungan dengan padi. Selain itu, mereka menambahkan sesaji yang terdiri atas seperangkat perlengkapan untuk perempuan, seperti selendang kain, kebaya, selendang, sisir, dan wewangian; juga makanan dan minuman kesukaannya, seperti rurujakan, kopi, susu, teh, air putih. Sesaji itu disajikan pada waktuwaktu tertentu, seperti pada malam Senin dan malam Kamis; disajikan di tempattempat yang digunakan untuk menyimpan padi atau beras, seperti di goah; dan disajikan pada kesempatankesempatan tertentu, seperti pada saat melaksanakan ritual upacara.

Kedua, mereka mempunyai kebiasaan melakukan ritual upacara ketika akan memulai atau mengakhiri sejumlah tahapan dalam aktivitas pertanian, baik di ladang maupun di sawah; atau ketika akan melakukan sesuatu terhadap padi. Tujuan upacara tersebut adalah untuk memberitahukan dan meminta izin kepada Dewi Sri karena akan melakukan sesuatu pada padi. Jangan sampai Dewi Sri merasa kaget, tersinggung, tersakiti, bahkan marah karena perilaku mereka. Yang ketiga, mereka harus mematuhi sejumlah aturan dan tabu yang berhubungan aktivitas pertanian dan perlakuan terhadap padi. Hal itu biasanya berkaitan 
dengan apa yang disenangi dan tidak disenangi oleh Dewi Sri.

Selain leluhur dan Dewi Sri, masih ada makhluk gaib lainnya yang mengisi dunia gaib di Kasepuhan Cicarucub. Masyarakat Kasepuhan Cicarucub memiliki sejumlah sebutan untuk makhluk gaib, di antaranya jin, setan iblis, dedemit, siluman, ririwa, jurig, dan kunti. Mereka menghuni berbagai tempat yang ada di alam nyata, seperti tinggal di pohon, sungai, hutan, sawah, gunung, jalan, tampian, tempat mandi, saung lesung, atau bahkan berada di rumah penduduk. Konon, jika suatu tempat dihuni oleh makhluk gaib, kesan angker atau menakutkan akan muncul dari tempat tersebut. Beberapa tempat yang dipercaya sering ada penghuninya adalah gunung, sungai, sawah, mata air, hutan, atau rumah kosong.

Masyarakat Kasepuhan Cicarucub percaya, makhluk gaib memiliki karakter yang beragam seperti layaknya manusia. Ada yang bersifat baik, dan ada juga yang bersifat buruk. Makhluk gaib yang baik tidak akan menggangu mereka, sehingga dapat hidup berdampingan secara damai. Pengecualian terjadi jika mereka secara sengaja atau tidak sengaja mengusik ketenangan makhluk gaib. Sementara itu, makhluk gaib yang tidak baik biasanya akan mencari peluang untuk menggangu ketenangan mereka. Seseorang yang diganggu oleh makhluk gaib biasanya memperlihatkan gejala kasantap ' kesurupan', atau sakit tanpa penyakit yang jelas.

Masyarakat Kasepuhan Cicarucub senantiasa berusaha untuk menjaga kehidupan yang harmonis dengan makhluk gaib, dalam arti tidak saling mengganggu satu sama lain. Ada beberapa tradisi yang dilakukan mereka untuk menjaga keharmonisan tersebut. Pertama, mereka memiliki tradisi numbal, yakni membakar kemenyan dan mengunyah panglay, kemudian menyemburkannya ke berbagai penjuru arah mata angin. Kemenyan hakikatnya merupakan sareat atau upaya untuk mendamaikan kehidupan manusia dengan berbagai makhluk gaib. Sementara itu panglay, hakikatnya merupakan harapan agar selamat, subur makmur, dan sejahtera. Khusus di tempat yang sangat angker atau menakutkan, tumbal biasanya dilengkapi dengan tenyo, yakni berupa getah pohon tenyo. Tenyo disimpan dalam plastik atau kertas, kemudian dibakar bersama kemenyan.

Kedua, mereka juga memiliki kebiasaan memasang babay sebagai penolak bala. Babay dibuat dari bahanbahan yang terdiri atas daun tulak tangul, daun darangdan, dan jukut palias. Daun tulak tangul dan daun darangdan terdapat di hutan, sedangkan jukut palias mudah ditemukan di sekitar kampung. Ketiga bahan tersebut tidak boleh dicuci, dan dibiarkan apa adanya. Kemudian ketiganya diikat menjadi satu menggunakan tali dari bambu. Selain satu ikat daun-daunan, babay juga dilengkapi dengan tulak angin yang berupa ketupat berukuran kecil, berisi beras, dan cangkang ketupatnya dibuat dari daun kelapa. Ketupat itu dimasak dengan cara direbus. Tulak angin dan satu ikatan daun disatukan dengan tali bambu menjadi babay.

Setiap keluarga di Kasepuhan Cicarucub memerlukan babay sebagai penolak bala dalam kehidupannya, yang jumlahnya minimal satu. Meskipun demikian, mereka tidak dapat sembarangan membuat babay, karena ada aturannya. Babay hanya boleh dibuat menjelang bulan Mulud untuk disertakan dalam ritual upacara menyambut pantang pertama. Olot biasanya menyediakan babay, minyak, dan kemenyan untuk seluruh warga kasepuhan. Sementara itu, warga menggantinya dengan uang dalam 
besaran yang tidak ditentukan, atau serelanya saja. Semua babay diletakkan di atas tampah bersama minyak, kemenyan, dan panglay. Perlengkapan tersebut sudah siap untuk disertakan dalam ritual upacara menyambut pantang pertama. Tujuan dari upacara tersebut adalah untuk memohon kebarokahan dan keselamatan bagi warga masyarakat Kasepuhan Cicarucub.

Upacara tersebut biasanya dilaksanakan sekitar tanggal 2 atau 3 Mulud atau Senin pertama pada bulan itu. Tempat pelaksanaan upacara harus di area yang terbuka, seperti di halaman atau tanah lapang, bukan di dalam bangunan. Alasan pemilihan tempat seperti itu agar doa-doa yang dipanjatkan tidak terhalang oleh apapun dan langsung sampai pada yang dituju.

Upacara menyambut pantang pada selasa pertama tersebut diisi dengan memperbanyak membaca syahadat dan salawat. Konon pada bulan Mulud, syahadat dan salawat itu diberi ketajaman yang lebih dibandingkan dengan bulanbulan lainnya. Setelah melaksanakan upacara tersebut, mereka memasuki masa istirahat atau pantang pada keempat hari Selasa yang ada pada bulan Mulud. Banyak hal yang tidak boleh dilakukan pada keempat hari selasa tersebut. Selain itu, babay juga mulai berfungsi sebagai penolak bala karena sudah disertakan dalam upacara yang dipimpin oleh olot. Oleh karena itu, babay dapat segera diletakkan di tempat yang semestinya.

Mereka memasang babay di atas pintu rumah bagian depan, pintu dapur, pintu masuk leuit 'lumbung padi', pintu kandang domba, pintu kandang ayam, dan pintu kandang kerbau. Dengan menempatkan babay di atas pintu, kekuatan gaib yang akan mengganggu ketenangan mereka yang ada dalam bangunan-bangunan tersebut dapat dicegah. Kekuatan untuk mengusir kekuatan gaib itu ada setelah babay disertakan dalam upacara menyambut pantang.

Setelah masyarakat Kasepuhan Cicarucub melakukan ritual upacara menyambut pantang, mereka akan melakukan masa istirahat atau pantang pada setiap hari Selasa atau pada keempat hari Selasa yang ada pada bulan Mulud. Pada hari-hari itu, mereka dilarang melakukan aktivitas pertanian atau aktivitas penting lainnya, seperti membangun rumah dan bepergian.

Selain memiliki hari pantang seperti itu, mereka juga masih memiliki larangan bulan, yakni perhitungan waktu dengan hari naas dan hari jayanya. Selengkapnya mengenai hal itu adalah sebagai berikut:

Pada bulan Muharam, Sapar, dan Mulud, hari naasnya jatuh pada hari Sabtu dan Minggu; sedangkan hari jayanya jatuh pada hari Rabu dan Kamis.

Pada bulan Silih Mulud, Jumadil Awal, dan Jumadil Akhir, hari naasnya jatuh pada hari Senin dan Selasa; sedangkan hari jayanya jatuh pada hari Jumat.

Pada bulan Rajab, Rewah, dan Puasa, hari naasnya jatuh pada hari Jumat; sedangkan hari jayanya jatuh pada hari Minggu.

Pada bulan Sawal, Hapit, dan Haji (Rayagung), hari naasnya jatuh pada hari Rabu dan Kamis; sedangkan hari jayanya jatuh pada hari Senin.

Masyarakat Kasepuhan Cicarucub tidak hanya mematuhi hari pantang dan larangan bulan, mereka juga mengambil tanggal lahir istrinya untuk memulai suatu aktivitas penting, seperti pertanian, pembelian barang, dan melakukan perjalanan atau bepergian. Tanggal dan hari lahir istrinya tidak terkena larangan bulan, yang ada masa naas dan masa jayanya. Dengan demikian, larangan bulan ini terabaikan oleh tanggal dan hari 
lahir istrinya. Pemuliaan tanggal dan hari lahir istrinya merupakan wujud penghormatan terhadap perempuan selayaknya kepada Dewi Sri, yang samasama perempuan.

Dari uraian tadi, tampak beragam tradisi yang dilakukan masyarakat Kasepuhan Cicarucub untuk menyatukan dunia nyata dan dunia gaib dalam rangka menjaga keharmonisan keduanya agar dapat hidup berdampingan secara damai. Ada aktivitas numbal, melaksanakan ritual upacara, mematuhi aturan dan pantangan tertentu, juga membuat penolak bala. Meskipun demikian, bukan berarti mereka dapat secara langsung melaksanakan semua tradisi tersebut. Secara adat, warga masyarakat tidak memiliki kewenangan untuk melakukan hal itu. Yang memiliki legitimiasi adat untuk hal itu adalah pemimpin adat mereka, yakni olot.

Olot memiliki kewenangan untuk memimpin, menyelenggarakan, dan mengontrol kelangsungan adat istiadat masyarakat Kasepuhan Cicarucub. Selain itu, dia juga mempunyai hak untuk memberikan sanksi atau mengingatkan akibat-akibat yang akan menimpa mereka jika melakukan pelanggaran terhadap adat. Sementara itu warga masyarakat Kasepuhan Cicarucub memiliki kewajiban untuk patuh kepada olot dan melaksanakan aturan adat di bawah komando olot.

Salah satu tugas olot adalah membangun hubungan yang harmonis antara masyarakat Kasepuhan Cicarucub yang hidup di dunia nyata dan entitas supranatural yang hidup di dunia gaib. Tugas tersebut dilaksanakan melalui jalur komunikasi secara gaib, dengan melakukan ritual yang disebut numbal. Pada hakikatnya numbal merupakan permohonan izin dan kiriman doa kepada entitas supranatural. Ada dua jenis doa yang dipanjatkannya, yakni doa rosul dan doa salamet. Doa rosul ditujukan kepada Tuhan dan rasulnya, sedangkan doa salamet ditujukan kepada leluhurnya juga Dewi Sri. Tujuan numbal adalah untuk meminta kelancaran, kebarokahan, dan keselamatan dalam melaksanakan setiap aktivitas penting. Selain itu, numbal juga merupakan upaya untuk mendamaikan masyarakat Kasepuhan Cicarucub dengan makhluk gaib.

Perlengkapan yang diperlukan untuk numbal terdiri atas kemenyan, panglay, dan sesaji. Kemenyan biasanya dibakar, sedangkan panglay biasanya dikunyah lalu disimburkeun (disemburkan). Kemenyan merupakan simbol sareat atau upaya untuk mendamaikan kehidupan manusia dengan berbagai makhluk gaib. Sementara itu panglay, hakikatnya merupakan harapan agar masyarakat Kasepuhan Cicarucub diberi keselamatan, kesuburan, kemakmuran, dan kesejahteraan. Dengan demikian, numbal menunjuk pada ritual berdoa sambil membakar kemenyan, menyemburkan panglay, dan menyajikan sesaji.

Olot melaksanakan numbal untuk dua kepentingan yang berbeda. Pertama, numbal untuk kepentingan umum atau kepentingan bersama, seperti ketika akan memulai aktivitas pertanian, memimpin berbagai upacara yang dilaksanakan secara kolektif. Dalam hal ini, dia melaksanakan sendiri numbal sepenuhnya, dari berdoa, menyajikan sesaji, hingga mengunyah panglay.

Kedua, olot melaksanakan numbal untuk melayani kepentingan warganya yang bersifat pribadi. Tentu saja beragam kepentingan pribadi warga masyarakat Kasepuhan Cicarucub. Beberapa contoh di antaranya adalah mengolah sawah pribadi, kepentingan yang berkaitan dengan aktivitas daur hidup, membangun rumah, dan masih banyak yang lainnya. Aktivitas pribadi apapun yang dipandang penting, sudah pasti akan diawali dengan 
numbal. Jika hal itu tidak dilakukan, mereka khawatir maksud dan rencananya tidak akan berjalan lancar. Untuk memenuhi kepentingan warganya, hampir setiap hari olot menerima kunjungan dari warganya yang ingin numbal.

Warga masyarakat Kasepuhan Cicarucub tidak dapat melaksanakan ritual numbal sendiri begitu saja, karena ada tatacara yang harus diikuti oleh mereka. Terlebih dahulu, mereka akan datang kepada olot untuk menyampaikan maksudnya, sekaligus meminta restu agar diberi keselamatan dan kelancaran dalam melaksanakan maksudnya. Ada yang datang sambil membawa kemenyan dan panglay, ada juga yang tidak membawa kedua perlengkapan tumbal seperti itu. Yang pasti, kemenyan dan panglay selalu tersedia di rumah olot.

Untuk memberikan restu kepada warga yang datang kepadanya, olot harus numbal terlebih dahulu. Olot akan berkomunikasi dengan entitas supranatural untuk menyampaikan maksud warganya. Dalam hal ini, dia berperan sebagai mediator antara warga kasepuhan dan entitas supranatural. Ketika pulang, warganya akan mendapat bekal tumbal berupa kemenyan dan panglay yang sudah diberi doa-doa khusus oleh olot. Bekal itu sebagai simbol restu yang sudah didapat dari entitas supranatural melalui olot. Selanjutnya, warga dapat melaksanakan numbal sendiri sesuai dengan kepentingannya masing-masing.

Kewenangan olot tidak hanya sebatas numbal, dia juga memimpin setiap ritual upacara yang dilaksanakan secara kolektif. Sementara itu, pelaksanakan ritual upacara yang dilaksanakan secara individu pun tetap harus ada restu darinya. Begitu pula dengan pembuatan penolak bala, masyarakat tidak dapat membuatnya sendiri. Sesuatu dipercaya akan berfungsi sebagai penolak bala jika telah disertakan dalam suatu upacara tertentu yang dipimpin oleh olot.

Jika pelaksanaan numbal, pelaksanaan ritual upacara, dan pembuatan penolak bala harus selalu berhubungan dengan restu olot, tidak demikian halnya dengan sejumlah aturan dan tabu yang ada di Kasepuhan Cicarucub. Sampai sejauh ini, masyarakat Kasepuhan Cicarucub masih teguh mematuhi berbagai tabu atau pantangan yang berlaku di tempat tersebut. Mereka memiliki kesadaran sendiri untuk tidak melanggar tabu yang menyangkut berbagai aspek kehidupan, seperti dalam bidang pertanian, daur hidup manusia, atau membangun rumah.

Hal itu dilakukan karena segala pelanggaran terhadap tabu akan berakibat langsung kepada mereka, bahkan juga dapat menimpa masyarakat kasepuhan secara keseluruhan. Oleh karena itu, mereka melakukan pengendalian sosial sendiri terhadap masalah tabu. Sementara itu, olot hanya bertindak memberi peringatan jika ada warganya yang melanggar tabu. Selebihnya, warga dipersilakan untuk menentukan sikap sendiri dalam masalah tabu dengan segala konsekuensinya.

\section{Penutup}

Sistem religi masyarakat Kasepuhan Cicarucub Provinsi Banten dibangun oleh dua hal. Pertama, agama yang dianut mereka, yakni agama Islam. Kedua, kepercayaan yang diwariskan secara turun temurun oleh nenek moyang mereka. Keduanya menjadi sumber nilai dan pedoman dalam melangsungkan kehidupan mereka sehari-hari secara harmonis.

Masyarakat Kasepuhan Cicarucub beragama Islam. Mereka meyakini ajaran agama yang dianutnya dengan melaksanakan aktivitas peribadatan, baik yang bersifat individu maupun kolektif. 
Peribadatan yang bersifat individu mencerminkan hubungan seseorang dengan Tuhannya. Berbeda dengan aktivitas peribadatan yang sifatnya kolektif. Aktivitas tersebut tidak sematamata mengekspresikan keyakinan mereka terhadap Tuhannya. Dalam aktivitas tersebut tercermin upaya membangun kebersamaan antarumat Islam di wilayah tersebut dalam rangka meningkatkan keimanan mereka. Tak heran di tempat tersebut tumbuh subur majelis taklim, dan aktivitas perayaan hari besar keagamaan yang melibatkan warga masyarakat Kasepuhan Cicarucub.

Mereka juga masih memelihara kepercayaan yang diwariskan secara turun temurun oleh leluhurnya. Kepercayaan tersebut tercermin dalam adat istiadat yang masih dipegang teguh dan dilaksanakan dalam kehidupan sehari-hari. Adat istiadat mereka tidak pernah lepas dari aspek kepercayaan tersebut.

Ada satu hal yang perlu direkomendasikan dari hasil penelitian tentang sistem religi pada Masyarakat Kasepuhan Cicarucub. Sistem religi pada masyarakat itu perlu mendapat perhatian dari berbagai pihak, khususnya pemerintah daerah setempat. Hal itu perlu dilakukan mengingat begitu banyak kearifan lokal yang terkandung di dalamnya. Kearifan lokal itu merupakan kristalisasi hasil adaptasi mereka dalam menghadapi lingkungannya. Bukan tidak mungkin, hal itu dapat diaplikasikan dalam membangun berbagai aspek kehidupan, seperti aspek spiritual bangsa.

\section{DAFTAR PUSTAKA}

Bustami, Abd. Latif. 2006. Monografi Komunitas Adat. Makalah dalam kegiatan Penyusunan Pedoman Inventarisasi Monografi Komunitas Adat.

Danandjaja, James. 1984.

Folklore Indonesia. Jakarta: Graffitipers.

Hidayah, Zulyani. 2006

Metodologi Penelitian "Kepercayaan" Masyarakat, Makalah dalam Penataran Tenaga Teknis Pamong, Jakarta 20 Desember.

Indrawardana, Ira. 2004.

Religi Sunda dalam Perputaran Roda Zaman. Makalah dalam kegiatan Sarasehan Pembinaan Penghayat Kepercayaan terhadap Tuhan YME, diselenggarakan oleh Balai Kajian Sejarah dan Nilai Tradisional Bandung, 26 Agustus.

Koentjaraningrat. 1989.

"Metode Wawancara", dalam Metode-Metode Penelitian Masyarakat. Jakarta: Gramedia.

Makmur K., Ade. 2003

Revitalisasi/Aktualisasi Nilai-nilai Ajaran Kepercayaan terhadap Tuhan Yang Mahaesa dalam Kehidupan Berbangsa dan Bernegara. Makalah dalam Sarasehan Kepercayaan terhadap Tuhan Yang Mahaesa, Bandung.

Rahayu. 2006.

Beberapa Hal tentang Kepercayaan terhadap Tuhan Yang Mahaesa. Makalah dalam Penataran Tenaga Teknis Pamong, Jakarta, 20 Desember. 